\title{
Interest in ICT Studies and Careers: Perspectives of Secondary School Female Students from Low Socioeconomic Backgrounds
}

\author{
Iwona Miliszewska and Ewa M. Sztendur \\ Victoria University, Melbourne, Victoria
}

\author{
Iwona.Miliszewska@vu.edu.au; Ewa.Sztendur@vu.edu.au
}

\begin{abstract}
The under-representation of females in information and communication technology (ICT) fields of study and careers continues to attract considerable attention. This article discusses findings of a research study that investigated interest in ICT studies and careers among female secondary school students. The investigation focused on girls from schools in the Western suburbs of Melbourne, Australia, home to families with low socio-economic status and students exposed to "educational disadvantage." The article outlines the demographic background of the participating girls, their experiences with ICT, self-efficacy of ICT skills, and their preferences for future studies and careers in ICT. It also analyzes factors that might have influenced the girls' attitudes towards ICT studies and careers, including their ethnic background, exposure to ICT at school and home, and perceptions of ICT. The article concludes with suggestions for future research.
\end{abstract}

Keywords: Computing self-efficacy, cultural differences, educational disadvantage, ethnic background, female secondary school students, ICT study and career.

\section{Introduction}

A 2006 government report on Building Australian ICT Skills recommended a number of areas to be addressed by government, industry, and education and training providers. One of the recommendations was a call for research on ICT skills in schools so as to identify the factors that contribute to deterring students from considering ICT as an option for further study at university or technical college and as a career choice (DCITA, 2006). In Australia, females continue to be largely under-represented in ICT courses (10\% to 30\%) and ICT-based careers (under 20\%), and the low participation rates have not improved in the past decade (Miliszewska, 2006; PartICipaTion Summit, 2005). Research suggests that ethnicity, race, and socio-economic status are related to low participation and attainment rates in ICT and, when gender and one of more of these factors are combined, there tends to be a cumulative effect (Blackmore, Hardcastle, Bamblett, \&

Owens, 2003).

Material published as part of this publication, either on-line or in print, is copyrighted by the Informing Science Institute. Permission to make digital or paper copy of part or all of these works for personal or classroom use is granted without fee provided that the copies are not made or distributed for profit or commercial advantage AND that copies 1) bear this notice in full and 2) give the full citation on the first page. It is permissible to abstract these works so long as credit is given. To copy in all other cases or to republish or to post on a server or to redistribute to lists requires specific permission and payment of a fee. Contact Publisher@InformingScience.org to request redistribution permission.
In response to the above issues, a research investigation was launched to examine the perceptions of female students from secondary schools in the Western Metropolitan Region of Melbourne towards ICT, ICT studies, and careers; students in this region have been identified as suffering from "entrenched educational disadvantage" (Teese, 2006). The research aimed to: 
- Examine attitudes and perceptions of the participating girls towards ICT careers and the skills perceived to be necessary to succeed in such careers;

- Investigate attitude differences related to ethnic background, year level, participation in ICT subjects, and coeducational versus all-girls schools with respect to computer usage and computer careers; and,

- Identify factors that influence female students' attitudes towards ICT and ICT careers.

It is now generally acknowledged by the government, business, employers, and the education and training sectors that there is an urgent need for improved targeting of information and advice on ICT studies and careers to students including secondary school students, with a particular goal to capturing girls' interest. To develop effective strategies to improve the advice, research is needed to first identify and debate key issues including female students' perception about the nature and scope of ICT work and occupations; the findings of this research may inform this identification and debate.

\section{Literature Review}

Low participation of women among the designers and creators of information technology has serious consequences, not only for women who are "missing the educational and economic opportunities that are falling into the laps of computer-savvy young men" (Margolis \& Fisher, 2002, p. 2), but also for a society increasingly influenced by technology. In the literature pertaining to women's under-representation in the ICT sector, a number of possible factors, such as geography, economy, cultural factors, race, and ethnicity, have been identified as having influence on girls' ICT career decisions (Trauth, 2006). In general, girls tend to report lower levels of interest in computers and lower levels of confidence in their abilities (Grass-Valazquez, Joyce, \& Derby, 2009; Hargittai \& Shafer, 2006; Volman \& van Eck, 2001; Volman, van Eck, Heemskerk, \& Kuiper, 2005). Some authors suggested that girls perceive ICT careers as boring, very technical, "nerdy,, and "geeky" (Babin, Grant, \& Sawal, 2008; Courtney, Timms, \& Anderson, 2006; Margolis \& Fisher, 2002). Others reported that females' choice of ICT courses or careers may be influenced by their intrinsic interest in computing as a field of study (Courtney et al., 2006), early exposure to computers, gender stereotypes (Adya \& Kaiser, 2005; Trauth, 2002; Volman \& van Eck, 2001; von Hellens \& Nielsen, 2005; von Hellens, Nielsen, \& Trauth, 2001), early exposure to advanced computing subjects (Craig, Fisher, \& Lang, 2007), and girls' abilities in mathematics and science (Margolis \& Fisher, 2002; Volman \& van Eck, 2001).

Girls are not well represented in science and technology courses in secondary schools and tertiary studies around the world, with African girls having the lowest enrolment rates in the world (Derbyshire, 2003; Eidelman \& Hazzan, 2006). Goode, Estrella, and Margolis (2006) and Moore (1994) found that students' attitudes and attraction to the ICT field of study were related to their experiences in ICT classes. Girls were found to perform much better in science and technology courses (Bosire, Mondoh, \& Barmao, 2008) or to have more positive attitudes toward ICT (Scott, 1996), if they were in single-sex classes or schools, rather than mixed-sex settings. According to Derbyshire (2003), who discussed the use of computers in education in Africa, the aspect of gender becomes particularly illuminated in classrooms where only a small number of computers are available to a large group of students. As Ratsatsi $(2002$, p. 47) pointed out "gender becomes an issue as the girl child and the boy child would behave differently when it comes to who sits in the driving seat at the computer...boys have the habit of running to the lab to take charge."

The choice of career is an important process in young people's life - a process that is often guided by a complex interplay of pressures, influences, and perceptions (IFACProject, 2008). Factors such as family background, parenting style, parental education and occupation, and socioeconomic status have been found to affect young girls' occupational aspirations and career 
choices (Adya \& Kaiser, 2005; Babin et al., 2008; Gates, 2002; von Hellens et al., 2001). For example, Babin et al. (2008) reported that twice as many female students (34\%) than male students $(17 \%)$ indicated that parents had influenced their career choices. In addition, girls' career choices have been found to be strongly influenced by their fathers (Gates, 2002; Trauth, 2002), as well as working and educated mothers (Smith, 2000). In a recent study by European Schoolnet (GrassValazquez et al., 2009), conducted in Italy, Poland, United Kingdom, Netherlands and France, female role models were also found to exert strong influence on girls' decisions regarding further study and careers. Interestingly, in Poland female students were most interested in ICT careers, compared to the other countries in the study, despite their parents' low level of knowledge in the ICT field. It is worth noting that, in this study, the majority of girls in all the evaluated countries enjoyed ICT studies and were competent users of computers and, yet, their interest did not translate into a potential interest in ICT careers.

Traditionally, young girls choose careers in "health, wellbeing, care, applied arts, such as clothing, graphic design ... contrary to young boys who select sectors that are related to mechanical engineering, electrical engineering, computers, and finance..." (IFACProject, 2008, p. 10). These views were confirmed by Symonds (2007), who examined students' patterns of future career choices in an English Midlands' city. In this study, male students were more likely to choose careers in engineering, followed by ICT, whereas female students' career interests were in education and health. Symonds (2007) pointed out that, although the two careers were popular choices for all girls, they were particularly common for female students from low SES. Further, this study revealed that the range of career choices became more limited with lower level of student achievement and socio-economic status. According to Klein (2007):

In an inequitable environment, students will make career choices based on limited factors, including family and personal demographic characteristics. Parent education and occupation, social class, and such factors as acculturation and discrimination all affect how students develop their career expectations. (p. 430)

\section{Methodology}

A survey instrument was developed to facilitate data collection from participating students. The survey included both structured (or closed) questions with pre-determined responses and several open-ended questions to give respondents the opportunity to elaborate on their views and motives. This was intended to allow researchers in this study to capture and study nuances of perceptions and attitudes that tend to go undetected in multiple-choice questions.

\section{Participants}

This study involved female students from seven government secondary schools: five from the urban Western suburbs of Melbourne, and two from outer Melbourne (the outer region). Of the 1,200 questionnaires that were distributed to students in this study, 464 were returned (a return rate of $39 \%$ ).

\section{Survey}

Questions in the survey were grouped in four sections. The first section aimed to determine students' demographic characteristics and provide information regarding students' family circumstances. The students were also asked if they had a computer and access to the Internet at home, and how much time they spent using those. In the next section questions pertaining to the students' ICT interests and skills were asked. The participants were required to indicate what kind of career they would like to pursue after finishing school and, more specifically, whether they would be interested in an ICT career, what kind of computing experience and level of skills they had, 
and whether they found computing interesting. Suggested choice of career options provided to students included: Architecture and Building, Agriculture and Environment, Creative Arts, Education, Engineering and Technologies, Health, Hospitality and Personal Services, Information Technology or ICT, Management and Commerce, Natural and Physical Sciences, and Society and Culture. Students were invited to select as many of these career options as they wished. To obtain information on other potential career interests, an open-ended question was also included in the survey. In addition to nominating future career choices, students were also asked to rate their ability to use computers. The next part of the survey aimed to determine students' perceptions and attitudes with respect to computer use in a classroom; for example, questions were asked to draw out if girls enjoyed classes in which computers were used and whether they found computers useful in their learning. Finally, the last section was designed to seek information regarding the participants' perceptions of gender differences with respect to computer use and interests.

\section{Data Analysis}

Chi-square $\left(\chi^{2}\right)$ tests were applied to determine if relationships between various student characteristic (categorical variables) were significant. The characteristics analyzed included student demographics, family characteristics, and school characteristics. In addition, a logistic regression model was developed to relate the outcome (response) variable, ICT as potential career, to a number of prospective factors (explanatory variables), that is, to determine how each of the factors affected the probability that a student would select ICT as a potential career. Logistic regression was used with a binary response variable which was coded 1 (occurrence of event) or 0 (absence of event) (Venables \& Ripley, 2002). In the current context, occurrence of the event for a particular student was "selecting ICT," while absence of the event represented "not selecting ICT." The model fitted to the student data was illustrated by effect displays (Fox, 2003), so that the effect of each factor could be easily interpreted. Statistical analyses were performed using the statistical computing environment $R$ ( $R$ Development Core Team, 2008).

\section{Findings}

\section{Participant Profile}

The respondents represented all year levels, with a nearly equal representation of $20 \%$ from each of Years 7, 10, 11, and 12. Participants from Years 8 and 9 together represented the remaining $20 \%$; however, there were no Year 9 participants from regional schools. Table 1 presents a summary of information about student profile 
Table 1: Student profile

\begin{tabular}{|c|c|}
\hline Characteristic & N (\%) \\
\hline Year level & \\
7 & $94(20)$ \\
8 & $60(14)$ \\
9 & $30(7)$ \\
10 & $87(19)$ \\
11 & $94(20)$ \\
12 & $94(20)$ \\
\hline School type & \\
Co-educational & $351(76)$ \\
Girls only & $113(24)$ \\
\hline Place of birth & \\
Australia & $361(78)$ \\
Other & $103(22)$ \\
\hline School location & \\
Urban & $308(67)$ \\
Regional & $156(33)$ \\
\hline \multicolumn{2}{|c}{} \\
\hline
\end{tabular}

As illustrated in Table 1 above, 22\% of the participants were born overseas (in 34 different countries). Table 2 shows the ethnic background of the participants grouped by broad geographical regions; ethnic background was determined by the parents' place of birth.

Table 2: Ethnic background grouped by geographical region

\begin{tabular}{|l|c|}
\hline \multicolumn{1}{|c|}{ Ethnic background } & N (\%) \\
\hline Australia and New Zealand & $255(55)$ \\
\hline Africa & $26(5)$ \\
\hline Asia & $107(23)$ \\
\hline Europe & $31(7)$ \\
\hline Pacific & $36(8)$ \\
\hline Middle East & $9(2)$ \\
\hline
\end{tabular}

Nearly $21 \%$ of all respondents indicated that they spoke only a language other than English at home. However, as illustrated in Table 3, the percentage varied for students of different ethnic backgrounds. For example, $83 \%$ of students of African background and born overseas did not speak English at home; whereas the corresponding percentages for those of Asian and Pacific background were $61 \%$ and $67 \%$ respectively, and $44 \%$ for students of European background. 
Interest in ICT Studies and Careers

Table 3: Language spoken at home by ethnic background and place of birth

\begin{tabular}{|c|c|c|c|}
\hline \multirow[b]{2}{*}{$\begin{array}{l}\text { Ethnic back- } \\
\text { ground }\end{array}$} & \multirow[b]{2}{*}{$\begin{array}{l}\text { Language spoken } \\
\text { at home }\end{array}$} & \multicolumn{2}{|c|}{ Place of birth } \\
\hline & & $\begin{array}{c}\text { Overseas } \\
\text { N (\%) }\end{array}$ & $\begin{array}{c}\text { Australia or NZ } \\
\text { N(\%) }\end{array}$ \\
\hline \multirow{3}{*}{$\begin{array}{l}\text { Australia and } \\
\text { New Zealand }\end{array}$} & No English & $\begin{array}{ll}0 & (0)\end{array}$ & $\begin{array}{ll}0 & (0)\end{array}$ \\
\hline & English & $8 \quad(89)$ & 237 (97) \\
\hline & English and other & 1 & $8 \quad(3)$ \\
\hline \multirow[t]{3}{*}{ Africa } & No English & $20 \quad(83)$ & $\begin{array}{ll}0 & (0)\end{array}$ \\
\hline & English & $1 \quad(4)$ & $1(50)$ \\
\hline & English and other & $3(13)$ & $1(50)$ \\
\hline \multirow[t]{3}{*}{ Asia } & No English & $28 \quad(61)$ & $18(29)$ \\
\hline & English & $1 \quad(2)$ & $4 \quad(7)$ \\
\hline & English and other & $17 \quad(37)$ & $39(64)$ \\
\hline \multirow[t]{3}{*}{ Europe } & No English & 4 (44) & $10(43)$ \\
\hline & English & $0 \quad(0)$ & $8(35)$ \\
\hline & English and other & $5 \quad(56)$ & $5(22)$ \\
\hline \multirow[t]{3}{*}{ Middle East } & No English & $\begin{array}{ll}0 & (0)\end{array}$ & $1(17)$ \\
\hline & English & $0 \quad(0)$ & $4(67)$ \\
\hline & English and other & $3(100)$ & $1(16)$ \\
\hline \multirow[t]{3}{*}{ Pacific } & No English & $\begin{array}{ll}8 \quad(67) \\
\end{array}$ & $7(29)$ \\
\hline & English & $0 \quad(0)$ & $1 \quad(4)$ \\
\hline & English and other & $4 \quad(33)$ & $16(67)$ \\
\hline
\end{tabular}

Almost all participants from the two schools outside of Melbourne (referred to in this article as 'regional') only spoke English at home (Table 4), which is not surprising considering their largely Anglo-Saxon background (93\% of the cohort), as presented in Table 5.

Table 4: Language spoken at home by school location and type

\begin{tabular}{|l|c|c|c|c|}
\hline \multirow{2}{*}{} & \multicolumn{2}{|c|}{ School location } & \multicolumn{2}{c|}{ School type } \\
\cline { 2 - 5 } & $\begin{array}{c}\text { Urban } \\
\mathbf{( \% )}\end{array}$ & $\begin{array}{r}\text { Regional } \\
\mathbf{( \% )}\end{array}$ & $\begin{array}{c}\text { All-girls } \\
\mathbf{( \% )}\end{array}$ & $\begin{array}{c}\text { Coeducational } \\
\mathbf{( \% )}\end{array}$ \\
\hline No English & 30 & 2 & 40 & 14 \\
\hline English & 38 & 95 & 27 & 67 \\
\hline English and other & 32 & 3 & 33 & 19 \\
\hline
\end{tabular}


Table 5: Ethnic background by school location and type

\begin{tabular}{|l|r|r|r|r|}
\hline & \multicolumn{2}{|c|}{ School location } & \multicolumn{2}{c|}{ School type } \\
\cline { 2 - 5 } & $\begin{array}{c}\text { Urban } \\
\mathbf{( \% )}\end{array}$ & $\begin{array}{r}\text { Regional } \\
(\mathbf{\%})\end{array}$ & $\begin{array}{c}\text { All-girls } \\
\mathbf{( \% )}\end{array}$ & $\begin{array}{c}\text { Coeducational } \\
\mathbf{( \% )}\end{array}$ \\
\hline Australia \& NZ & 36 & 93 & 22 & 43 \\
\hline Africa & 8 & 0 & 20 & 2 \\
\hline Asia & 34 & 3 & 41 & 30 \\
\hline Europe & 8 & 4 & 3 & 11 \\
\hline Middle East & 3 & 0 & 4 & 2 \\
\hline Pacific & 11 & 0 & 10 & 12 \\
\hline
\end{tabular}

\section{Family Background}

Two thirds (65\%) of the respondents reported living with both parents, 30\% lived with mother only, $4 \%$ lived with father only, and $1 \%$ reported living with other family. While $50 \%$ of respondents came from families with both parents in employment, $12 \%$ of girls indicated that none of their parents was employed. Nearly half of the girls (45\%) came from families where both parents were born overseas.

A summary of family-related demographic information is presented in Table 6.

Table 6: Family-related demographic information

\begin{tabular}{|l|r|l|r|}
\hline Environmental factor & N (\%) & Environmental factor & N (\%) \\
\hline Living at home with & & Mother's education & \\
Both parents & $300(65)$ & $0-6$ years & $38(8)$ \\
Mother only & $140(30)$ & $7-10$ years & $105(23)$ \\
Father only & $17(4)$ & $11-12$ years & $194(42)$ \\
Other family & $7(1)$ & Post-secondary & $97(21)$ \\
& & Missing data & $30 \quad(6)$ \\
\hline Parents employed & & Father's education & \\
Both & $218(50)$ & $0-6$ years & $30 \quad(6)$ \\
Only mother & $39(9)$ & $7-10$ years & $109(24)$ \\
Only father & $128(29)$ & $11-12$ years & $169(36)$ \\
None & $55(12)$ & Post-secondary & $97(21)$ \\
& & Missing data & $59(13)$ \\
\hline Parents born in Australia & & Parents use computers & \\
Both & $181(39)$ & Mother & $291(63)$ \\
Only one & $68(15)$ & Father & $271(58)$ \\
None & $212(45)$ & & \\
Missing data & $3(1)$ & & \\
\hline
\end{tabular}

The disaggregation of family-related information according to school location and type revealed differences between girls from urban and regional schools, as well as all-girls versus coeducational schools. As illustrated in Table 7, a much greater percentage of girls from urban schools reported that both their parents were unemployed (17\%), as opposed to girls from regional schools $(3 \%),\left(\chi^{2}(3, N=440)=44.59, p<0.001\right)$. Likewise, a much greater percentage of girls from 
all-girls school had both parents unemployed (27\%), than girls from coeducational schools (8\%), $\left(\chi^{2}(3, N=440)=31.46, p<0.001\right)$. Regardless of school location and type, girls from African background represented the most disadvantaged cohort in terms of parental unemployment $-33 \%$ of them came from families where both parents were unemployed.

The responses also revealed considerable differences with respect to parental origin, that is, parents' place of birth; $65 \%$ of girls from urban schools reported that both their parents were born overseas, as opposed to $8 \%$ of girls from regional schools $\left(\chi^{2}(2, N=461)=153.96, p<0.001\right)$. Similarly, the majority of girls from all-girls school had both parents born overseas $(81 \%)$, while only a third (35\%) of girls from coeducational schools reported the same $\left(\chi^{2}(2, N=461)=75.08\right.$, $p<0.001)$.

Table 7: Family context by school location and type

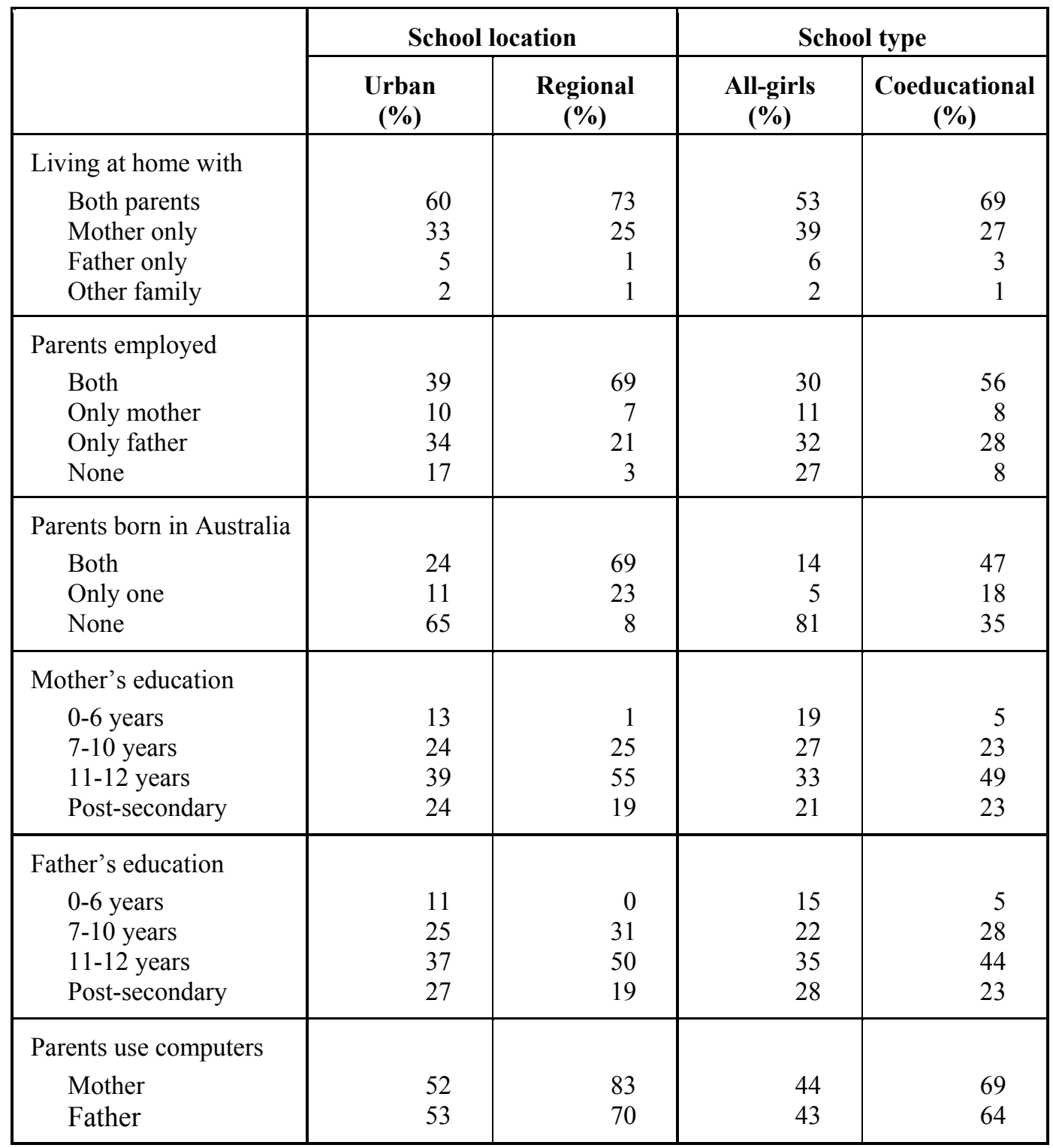

Table 7 also shows differences in parents' educational background. Parents of girls from urban schools had a greater percentage of parents with lower level of education as compared to girls 
from regional schools. For example, $13 \%$ of girls from urban schools had mothers with, at most, primary level education, as opposed to $1 \%$ of girls from regional schools; $\left(\chi^{2}(3, N=434)=30.44\right.$, $p<0.001)$. Similarly, $11 \%$ of girls from urban schools had fathers with, at most, primary level education, as opposed to $0 \%$ of girls from regional schools; $\left(\chi^{2}(3, N=434)=19.20, p<0.001\right)$. The differences were almost as pronounced for girls from all-girls versus coeducational schools: $19 \%$ of mothers and $15 \%$ of fathers, as opposed to $5 \%$ of mothers and $5 \%$ of fathers with only primary education; again, the differences were statistically significant at $p<0.001$. The largest percentage of girls who had both parents with at most primary level of education were of African and Asian backgrounds ( $12 \%$ and $13 \%$ respectively).

Girls participating in the study were also asked to provide information about their parents' use of computers. According to their responses, $63 \%$ of mothers and $58 \%$ of fathers (as presented in Table 6) have used computers. However, as illustrated in Table 7, there were differences in the use of computers between the parents of students from urban and regional schools; $52 \%$ of girls from urban schools had mothers who used computers, as opposed to $83 \%$ of girls from regional schools $\left(\chi^{2}(1, N=464)=41.41, p<0.001\right)$. Similarly, $53 \%$ of girls from urban schools had fathers who used computers, as opposed to $70 \%$ of girls from regional schools $\left(\chi^{2}(1, N=464)=11.14, p<0.001\right)$.

The use of computers by parents differed also for girls from all-girls school and coeducational schools; $44 \%$ of girls in all-girls school had mothers who used computers, as opposed to $69 \%$ of girls in coeducational schools $\left(\chi^{2}(1, N=464)=20.76, p<0.001\right)$; and, $43 \%$ of girls from all-girls school had fathers who used computers, as opposed to $64 \%$ of girls from coeducational schools $\left(\chi^{2}(1, N=464)=15.62, p<0.001\right)$.

\section{Computer and Internet Access and Use}

Overall, the majority of girls reported having access to a computer (97\%) and the Internet $(90 \%)$ at home. However, $27 \%$ of girls of African background did not have a computer at home; this is a noticeable figure considering that the corresponding percentages for girls from the other ethnic groups varied between a mere $1 \%$ for girls of Asian background to 3\% for girls of Pacific background.

Of those who had a computer at home, $42 \%$ reported using it, on average, for 1-5 hours per week; likewise, $35 \%$ of respondents reported using the Internet for $1-5$ hours per week. Almost $17 \%$ of students reported spending more than 20 hours a week on a computer. Table 8 shows the details of weekly usage of computer and the Internet at home.

Table 8: Weekly usage of computer and Internet at home

\begin{tabular}{|c|c|c|}
\hline $\begin{array}{l}\text { Hours per } \\
\text { Week }\end{array}$ & $\begin{array}{r}\text { Computer } \\
\text { N }(\%)\end{array}$ & $\begin{array}{l}\text { Internet } \\
\text { N (\%) }\end{array}$ \\
\hline 0 & $13 \quad(3)$ & $27 \quad(6)$ \\
\hline $1-5$ & $193(42)$ & $162(35)$ \\
\hline $6-10$ & $102(22)$ & 115 \\
\hline $11-20$ & $76(16)$ & $61(13)$ \\
\hline $21-39$ & $36 \quad(8)$ & $29 \quad(6)$ \\
\hline $40-79$ & $16 \quad(3)$ & $16 \quad(3)$ \\
\hline 80 and more & $(2)$ & $(1)$ \\
\hline Missing data & (4) & $50(11)$ \\
\hline
\end{tabular}


Of those who answered the question, the majority of respondents (75\%) reported that they started using computers when they were 6-11 years old. However, the starting age varied for students from different ethnic backgrounds. As illustrated in Table 9, the earliest "starters" were students of an Australian \& New Zealand background; on the other hand, 32\% of students of an African background only started using computers at the age of 12 or older.

Table 9: Age when started using computer by ethnic background

\begin{tabular}{|l|r|r|r|r|}
\hline & $\begin{array}{c}\text { Less than 5 } \\
\text { N (\%) }\end{array}$ & $\begin{array}{c}\mathbf{6 - 1 1} \\
\mathbf{N}(\%)\end{array}$ & $\begin{array}{c}\text { 12 and older } \\
\text { N (\%) }\end{array}$ & $\begin{array}{r}\text { Total } \\
\mathbf{N}\end{array}$ \\
\hline Australia \& NZ & $39(16)$ & $187(77)$ & $16(7)$ & 242 \\
\hline Africa & $0(0)$ & $17(68)$ & $8(32)$ & 25 \\
\hline Asia & $0(0)$ & $85(81)$ & $20(19)$ & 105 \\
\hline Europe & $3(10)$ & $24(77)$ & $4(13)$ & 31 \\
\hline Middle East & $0(0)$ & $8(89)$ & $1(11)$ & 9 \\
\hline Pacific & $1(3)$ & $28(80)$ & $6(17)$ & 35 \\
\hline
\end{tabular}

The participants were asked if they used computers to complete homework, and if so, to indicate what kind of software they used. Almost all girls (95\%) indicated that they used a computer for homework; $91 \%$ of students used Word, 27\% of them used Excel, and 57\% used Power Point; students also reported using Publisher (6\%) and the Internet (8\%). Other software mentioned by the students included MS Access, Photoshop, and FrontPage.

Students also responded to questions about computing skills or topics that they had learned or discussed at school so far. As presented in Table 10, the majority of girls indicated that they had used word-processing (78\%) and multimedia presentations (75\%). Half of the respondents used Web surfing (54\%) and used spreadsheets $(50 \%)$; $39 \%$ of girls learned how to set up web pages, and $38 \%$ used email. Interestingly, final-year students reported a much lower level of exposure to the more advanced computing skills such as database skills, programming, and Web data retrieval, than students in the earlier year level.

Table 10: Technology/software use at school by year level

\begin{tabular}{|l|r|r|r|r|r|r|r|}
\hline & $\begin{array}{c}7 \\
\mathbf{( \% )}\end{array}$ & $\begin{array}{c}\mathbf{8} \\
\mathbf{( \% )}\end{array}$ & $\begin{array}{c}\mathbf{9} \\
\mathbf{( \% )}\end{array}$ & $\begin{array}{c}\mathbf{1 0} \\
\mathbf{( \% )}\end{array}$ & $\begin{array}{c}\mathbf{1 1} \\
\mathbf{( \% )}\end{array}$ & $\begin{array}{c}\mathbf{1 2} \\
\mathbf{( \% )}\end{array}$ & $\begin{array}{c}\text { Total } \\
\mathbf{N}(\%)\end{array}$ \\
\hline Word processing & 69 & 72 & 80 & 75 & 85 & 88 & $360(78)$ \\
\hline Multimedia presentations & 62 & 77 & 70 & 77 & 80 & 83 & $345(75)$ \\
\hline Web surfing & 45 & 47 & 47 & 59 & 65 & 55 & $248(54)$ \\
\hline Spreadsheets & 26 & 60 & 37 & 47 & 63 & 62 & $229(50)$ \\
\hline Setting up Web sites & 18 & 45 & 57 & 41 & 47 & 42 & $180(39)$ \\
\hline E-mail exchange & 23 & 28 & 20 & 47 & 47 & 49 & $176(38)$ \\
\hline Web data retrieval & 16 & 12 & 13 & 18 & 25 & 16 & $80(17)$ \\
\hline Programming & 11 & 13 & 13 & 22 & 22 & 17 & $78(17)$ \\
\hline Database software & 6 & 13 & 10 & 13 & 25 & 16 & $66(14)$ \\
\hline
\end{tabular}


Table 11 presents a breakdown of technology use at school by school location and type. The use of technologies that could be considered useful in a variety of schoolwork tasks, such as wordprocessing, multimedia presentation, or spreadsheets, was similar across urban and regional, as well as all-girls and coeducational school girls. However, girls from urban schools engaged in computer programming considerably more $(20 \%)$ than girls from regional schools $(12 \%),\left(\chi^{2}(1\right.$, $N=464)=4.12, p<0.05)$; the use of database software was also significantly higher for girls from urban schools $(17 \%)$ than from regional schools $(8 \%),\left(\chi^{2}(1, N=464)=5.98, p<0.05\right)$.

Girls from all-girl schools exchanged emails less than girls from coeducation schools, $25 \%$ and $43 \%$ respectively, $\left(\chi^{2}(1, N=464)=5.98, p<0.05\right)$. However, girls from coeducational schools were less engaged in setting up websites $(36 \%)$ than girls from all-girls school $(50 \%),\left(\chi^{2}(1\right.$, $N=464)=7.28, p<0.01)$. Furthermore, girls from coeducational schools used database software less than girls from all-girls school ( $11 \%$ and $24 \%$ respectively $),\left(\chi^{2}(1, N=464)=10.42, p<0.001\right)$.

Table 11: Technology/software use at school by school location and type

\begin{tabular}{|l|c|c|c|c|}
\hline \multirow{2}{*}{} & \multicolumn{2}{|c|}{ School location } & \multicolumn{2}{c|}{ School type } \\
\cline { 2 - 5 } & $\begin{array}{c}\text { Urban } \\
\mathbf{( \% )}\end{array}$ & $\begin{array}{r}\text { Regional } \\
\mathbf{( \% )}\end{array}$ & $\begin{array}{c}\text { All-girls } \\
\mathbf{( \% )}\end{array}$ & $\begin{array}{c}\text { Coeducational } \\
\mathbf{( \% )}\end{array}$ \\
\hline Word processing & 76 & 83 & 74 & 80 \\
\hline Multimedia presentations & 74 & 78 & 81 & 74 \\
\hline Web surfing & 55 & 53 & 48 & 56 \\
\hline Spreadsheets & 47 & 56 & 50 & 50 \\
\hline Setting up Web sites & 36 & 45 & 50 & 36 \\
\hline E-mail exchange & 36 & 43 & 25 & 43 \\
\hline Web data retrieval & 18 & 17 & 20 & 16 \\
\hline Programming & 20 & 12 & 22 & 15 \\
\hline Database software & 17 & 8 & 24 & 11 \\
\hline
\end{tabular}

In terms of using computers for entertainment, $95 \%$ of girls reported using computer for such purposes. Social networks appeared to be the most popular choices, with $58 \%$ of girls reporting using MySpace and 33\% Facebook; a further 10\% of girls reported using Bebo. As presented in Table 12, the reported use of social networking sites was considerably higher among girls from regional schools than from urban schools; MySpace, $67 \%$ versus $54 \%,\left(\chi^{2}(1, N=461)=7.24\right.$, $p<0.01)$; and, Facebook, $41 \%$ versus $30 \%,\left(\chi^{2}(1, N=461)=5.65, p<0.05\right)$. Similarly, girls from coeducational schools used MySpace and Facebook noticeably more than their counterparts from all-girls school, and the differences were statistically significant $\left(\chi^{2}(1, N=461)=5.61, p<0.05\right.$ and $\chi^{2}(1, N=461)=12.48, p<0.001$, respectively).

Computer games were used by $54 \%$ of respondents, and chatrooms by $40 \%$ of them. While the use of computer games was equally popular among urban and regional students, it was considerably more popular with girls from all-girls school $(66 \%)$ than coeducational schools $(50 \%),\left(\chi^{2}(1\right.$, $N=461)=7.94, p<0.01)$. Chatrooms were significantly more popular with the urban users $(45 \%)$ than regional ones $(30 \%),\left(\chi^{2}(1, N=461)=9.12, p<0.01\right)$; and, girls from all-girls school used chatrooms more than girls from coeducational schools (59\% versus $34 \%),\left(\chi^{2}(1, N=461)=20.80\right.$, $p<0.001)$. 
Table 12: The use of computer for entertainment by school location and type

\begin{tabular}{|l|c|c|c|c|}
\hline \multirow{2}{*}{} & \multicolumn{2}{|c|}{ School location } & \multicolumn{2}{c|}{ School type } \\
\cline { 2 - 5 } & $\begin{array}{c}\text { Urban } \\
\mathbf{( \% )}\end{array}$ & $\begin{array}{r}\text { Regional } \\
\mathbf{( \% )}\end{array}$ & $\begin{array}{c}\text { All-girls } \\
\mathbf{( \% )}\end{array}$ & $\begin{array}{c}\text { Coeducational } \\
\mathbf{( \% )}\end{array}$ \\
\hline MySpace & 54 & 67 & 48 & 62 \\
\hline Facebook & 30 & 41 & 19 & 38 \\
\hline Chatroom & 45 & 30 & 59 & 34 \\
\hline Games & 53 & 56 & 66 & 50 \\
\hline Forum & 12 & 6 & 17 & 8 \\
\hline Skype & 10 & 6 & 9 & 8 \\
\hline
\end{tabular}

\section{Perceptions of Computers and Self-efficacy (Including Gender Differences)}

The majority of female students in this study felt confident in their ability to use computers; $15 \%$ of them rated their skills as excellent; $50 \%$ as very good; $31 \%$ as good; and only $4 \%$ reported poor computer skills. Students' perceptions regarding the usefulness of computers in their learning environment were very positive. All students thought computers helped them find new information; $89 \%$ of girls indicated that they enjoyed classes in which computers were used; $89 \%$ thought that students should learn about computers at school; $75 \%$ would like to use computers more often in school; and, 80\% thought computers helped them learn more easily.

In terms of the importance of ICT education, $66 \%$ of students felt that it would enhance their knowledge; $59 \%$ agreed that ICT education would help them function in modern society; and, $47 \%$ believed that it would help them in pursuing their future career. Only $33 \%$ of participants felt that ICT would increase their social interests, and 31\% thought that it would improve their communication ability.

As illustrated in Figure 1, girls from urban schools displayed a greater appreciation of the general benefits of ICT education than their counterparts from regional schools. Similarly, girls from allgirls school recognized ICT benefits more than girls from coeducational schools (Figure 2). In particular, there was a significant difference with respect to the perceived benefit of ICT in helping to pursue future career $\left(\chi^{2}(1, N=461)=34.07, p<0.001\right)$. 


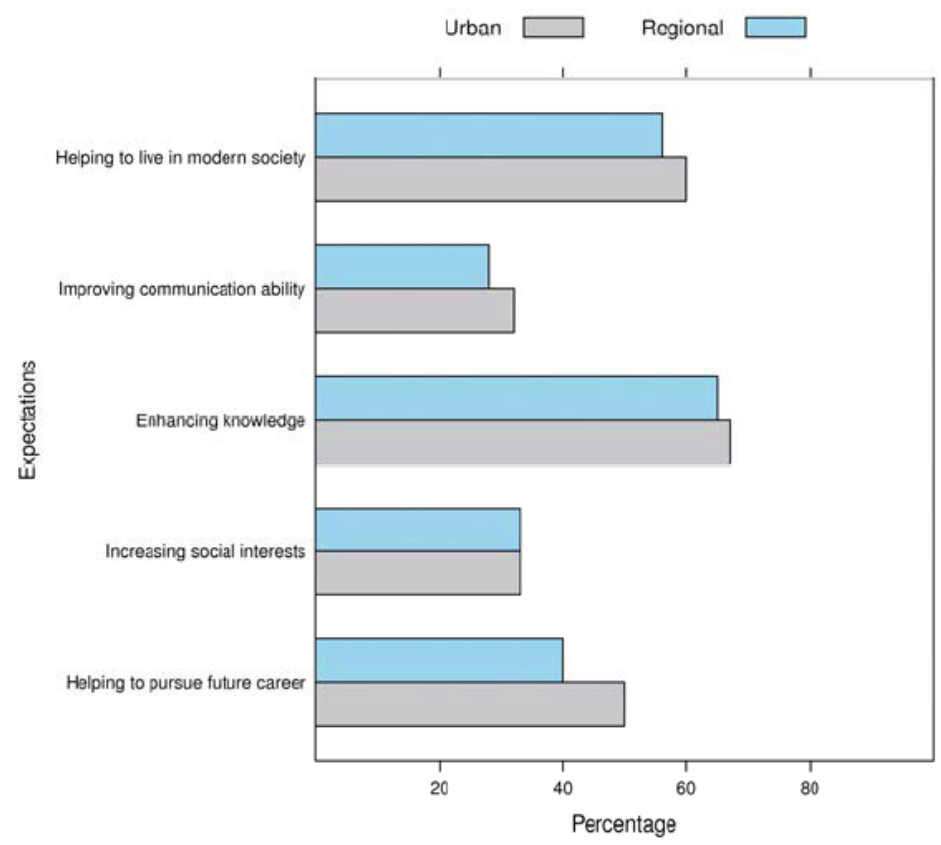

Figure 1: Expectations of ICT education by school location

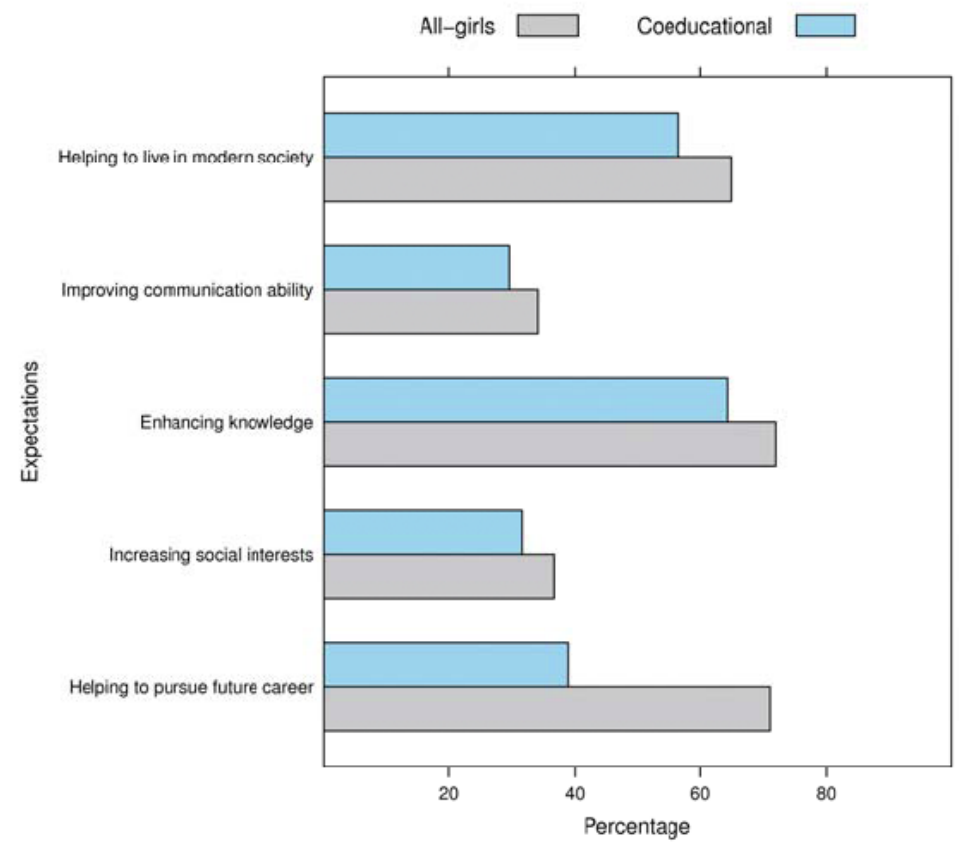

Figure 2: Expectations of ICT education by school type

The majority of girls $(82 \%)$ were of the view that girls knew how to use computers as well as boys; yet, $52 \%$ of them thought that boys were more interested in computers than girls. While the level of assertiveness about girls' computing knowledge, as compared to boys, was the same 
among all girls, those from coeducational schools were significantly more likely to believe that boys were more interested in computers than girls $\left(\chi^{2}(1, N=451)=7.00, p<0.01\right)$.

\section{ICT Interest and Career Plans}

Overall, girls found computers interesting (50\%) or very interesting (31\%); $17 \%$ were only somewhat interested in computers, and the remaining $2 \%$ found computers boring. Of the girls who were either interested or very interested in computers, $75 \%$ wanted to develop their computing skills further. On the other hand, only $45 \%$ of the girls who found computers either boring or moderately interesting were willing to develop further computer skills.

Respondents were asked to provide reasons for wanting, or not wanting, to develop computer skills further. The reasons for wanting to develop ICT skills did not differ according to year level, ethnic background, or type, or location of the school; the reasons ranged from the pragmatic, through reflective, to future-looking:

'To complete homework easier'.

'You need computer skills to get a job.'

'To learn new things'.

'To learn more complicated skills needed for work and everyday life.'

'Yes, because having any knowledge of computers will always come in handy.'

'To improve my computer skills and also to use these skills in my future career; to keep myself up-to-date with IT.'

'They are only going to become more important in society so having a good knowledge of them would be beneficial.'

'To be able to do well in my field and be up to date with $21^{\text {st }}$ century technology.'

'To be able to do more and show others how to and what to do.'

On the other hand, the justification for not wanting to develop their computing skills any further varied between girls from the different ethnic backgrounds. Girls of European, Middle Eastern, and Australian/NZ backgrounds were least interested in developing further computing skills. While the girls from Australian/NZ backgrounds presented a variety of reasons, there was an interesting distinction between the reasons given by girls from the other ethnic backgrounds. Those of Middle Eastern background did not want to do it because of lack of interest:

'No, not really, because I am not really interested.'

'Because I am not very interested in computers.'

'Because I want to do something I really love and computing isn't what I want to do.'

In contrast, the girls of European background felt that they knew a great deal about ICT already and did not see the need to develop further skills:

'Because I know enough to do what I need.'

'Because I already know a lot of things.'

'Because I don't need to. I know as much as I need to know to do what I need to do and that's enough.' 
'Because I know enough at the moment to help me with my homework \& other interests. And I don't want to pursue a career in ICT \& therefore don't think it is very necessary.'

Nearly one third (29\%) of the participating girls stated that they had no interest in an ICT career at all, 37\% were 'somewhat interested', $24 \%$ were interested, and 10\% were very interested. Although overall $34 \%$ of girls declared to be either interested or very interested in an ICT career, their choice of future careers did not seem to reflect this claim. The responses presented in Table 13 indicate that the girls opted for careers commonly regarded as "feminine;" their choice of potential career included Creative Arts (30\%), Health (28\%), Society \& Culture (20\%) and Education (20\%). While 52 girls (11\%) also nominated ICT as their career of choice, only 8 of those selected ICT as the only career option. The interest in ICT careers was similar to that in Natural and Physical Sciences and marginally exceeded the interest in engineering disciplines.

Table 13: Future career interest

\begin{tabular}{|l|c|c|}
\hline Career field & $\begin{array}{c}\text { One of many selections } \\
\text { N (\%) }\end{array}$ & $\begin{array}{c}\text { Only selection } \\
\text { N }\end{array}$ \\
\hline Creative Arts & $141(30)$ & 39 \\
\hline Health & $132(28)$ & 47 \\
\hline Society and Culture & $94(20)$ & 47 \\
\hline Education & $94(20)$ & 30 \\
\hline Hospitality and Personal Services & $86(19)$ & 15 \\
\hline Management and Commerce & $61(13)$ & 16 \\
\hline Natural and Physical Sciences & $54(12)$ & 14 \\
\hline Information Technology or ICT & $52(11)$ & 8 \\
\hline Engineering and Technology & $32(7)$ & 8 \\
\hline Architecture and Building & $26(6)$ & 2 \\
\hline Agriculture and Environment & $14(3)$ & 2 \\
\hline
\end{tabular}

\section{ICT as Potential Career - Statistical Modeling}

Binary logistic regression method was used to determine the relationship between the response variable and a number of explanatory variables concerning student environmental factors. The variables in the model were as follows:

- The response variable, ICT as potential career, coded as (0) - if a student did not select ICT as one of potential areas of future study, and (1) if a student selected ICT as one of potential areas.

- Explanatory variables included:

- Student school level (Year 7 - Year 12); school location (Urban, Regional); type of school (All-girls, Coeducational); computer access at home (Yes/No); ethnic background (Australia and New Zealand, Asia, Europe, Pacific); age of first starting using computers $(0-5,6-11,12$ and older); mother's education $(0-6,7-10,11-12$, Postsecondary) and father's education (0-6, 7-10, 11-12, Post-secondary); whether mother uses a computer at home (Yes/No); whether father uses a computer at home 
(Yes/No); whether mother helps with computer questions (Yes/No); and whether father helps with computer questions (Yes/No);

- Number of different software packages/tools used/discussed at school; number of different software used for leisure; hours spent using a computer;

- Level of interest in computers (boring, only somewhat interesting, interesting, very interesting); self-efficacy (poor, good, very good, excellent); willingness to develop computer skills (Yes/No);

- Indication of whether girls know how to use computers as well as boys (Yes/No); whether boys are more interested than girls in computers (Yes/No);

A forward stepwise method for variables selection, using Akaike's Information Criterion (AIC), was applied. AIC is a measure computed separately for each model under consideration. AIC chooses models that fit well with a penalty for models that have too many variables (Venables \& Ripley, 2002). The "best" model, based on the minimum value of AIC, is selected. Estimated coefficients and their standard errors, as well as $t$-values from a final model are provided in Table 14. It should be noted that factors "ethnic background" and "mother's education" should be interpreted in terms of the "absent" reference categories, "Australia \& New Zealand" and "0-6", respectively.

Table 14: Coefficient for logistic regression model regressing students' potential in ICT career on socio-cultural factors

\begin{tabular}{|l|c|c|c|}
\hline \multicolumn{1}{|c|}{ Variable } & $\begin{array}{c}\text { Coefficient } \\
\text { Value }\end{array}$ & $\begin{array}{c}\text { Standard } \\
\text { Error }\end{array}$ & $\boldsymbol{Z}$ \\
\hline Number of software tools used at school & 0.36 & 0.09 & $3.82^{* * * *}$ \\
Coeducational school & -0.70 & 0.47 & -1.50 \\
Year Level & -0.30 & 0.13 & $-2.36^{* *}$ \\
Ethnic background: & & & \\
$\quad$ Africa & 1.49 & 0.87 & $1.71^{*}$ \\
Asia & 0.82 & 0.49 & $1.65^{*}$ \\
Europe & 0.49 & 0.72 & 0.68 \\
$\quad$ Pacific & 0.74 & 0.76 & 0.97 \\
Mother's education & & & \\
7-10 & 0.94 & 0.88 & 1.07 \\
11-12 & 1.49 & 0.87 & $1.72^{*}$ \\
Post-secondary & 1.16 & 0.92 & 1.26 \\
Mother uses computer & -1.07 & 0.46 & $-2.31^{* *}$ \\
Father uses computer & 0.73 & 0.45 & $1.65^{*}$ \\
\hline
\end{tabular}

Significant at: $\alpha=0.001 \quad(* * *), \alpha=0.01 \quad(* * *), \alpha=0.05 \quad(* *), \alpha=0.1 \quad(*)$

Figure 3 - Figure 8 convey the results of this model in a more clear and informative way, showing fitted relationships between the response variable and significant explanatory variables. The pattern in Figure 3 indicates that the higher the students' exposure to different software tools at school, the higher the likelihood that they will consider ICT as a career option. Figure 4 shows that girls in earlier years of secondary school are more likely to consider ICT as a career option. 


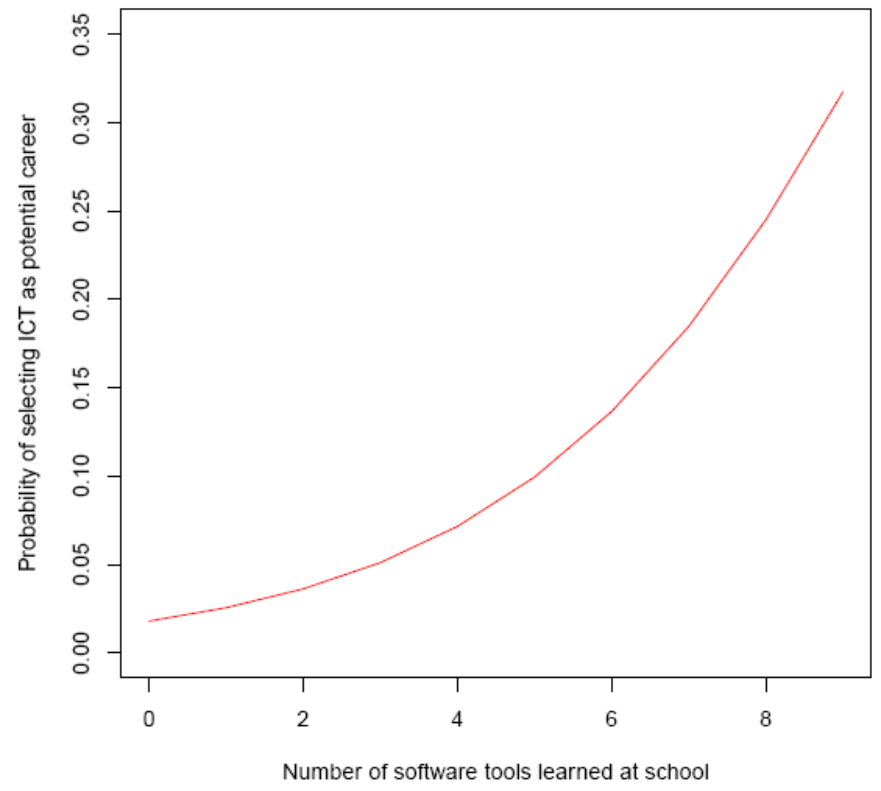

Figure 3: Fitted relationship between exposure to software tools and interest in ICT career

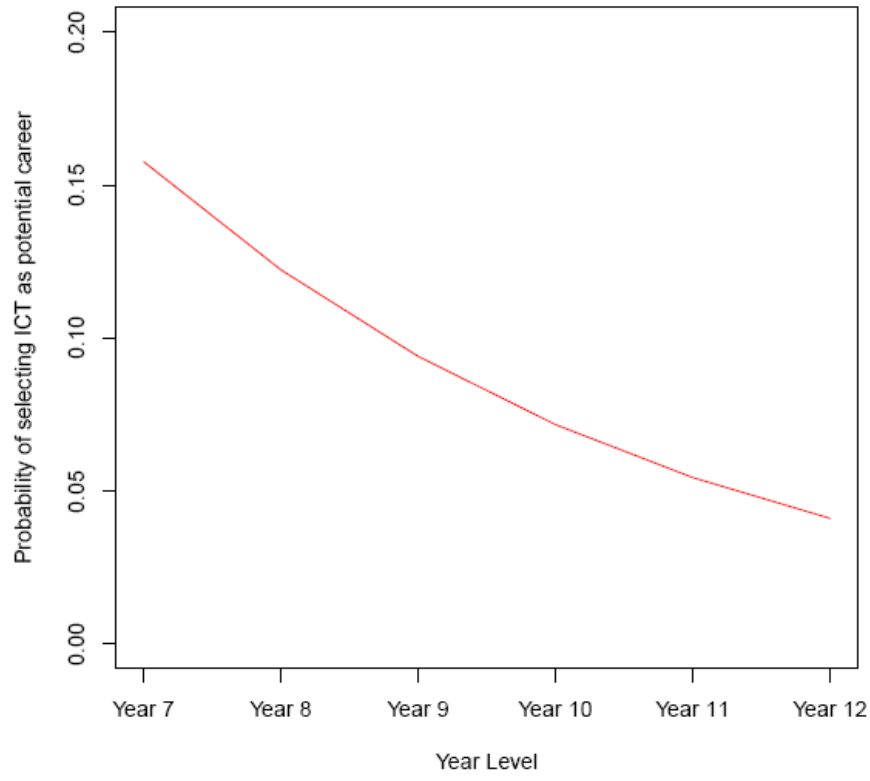

Figure 4: Fitted relationship between year level and interest in ICT career 
The pattern in Figure 5 reveals quite an interesting finding. Girls of an immigrant background were more likely to be interested in an ICT career than those whose both parents were born in Australia or New Zealand. Moreover, students of African background showed the highest interest in an ICT career, followed by students who immigrated from Asia and the Pacific Islands.

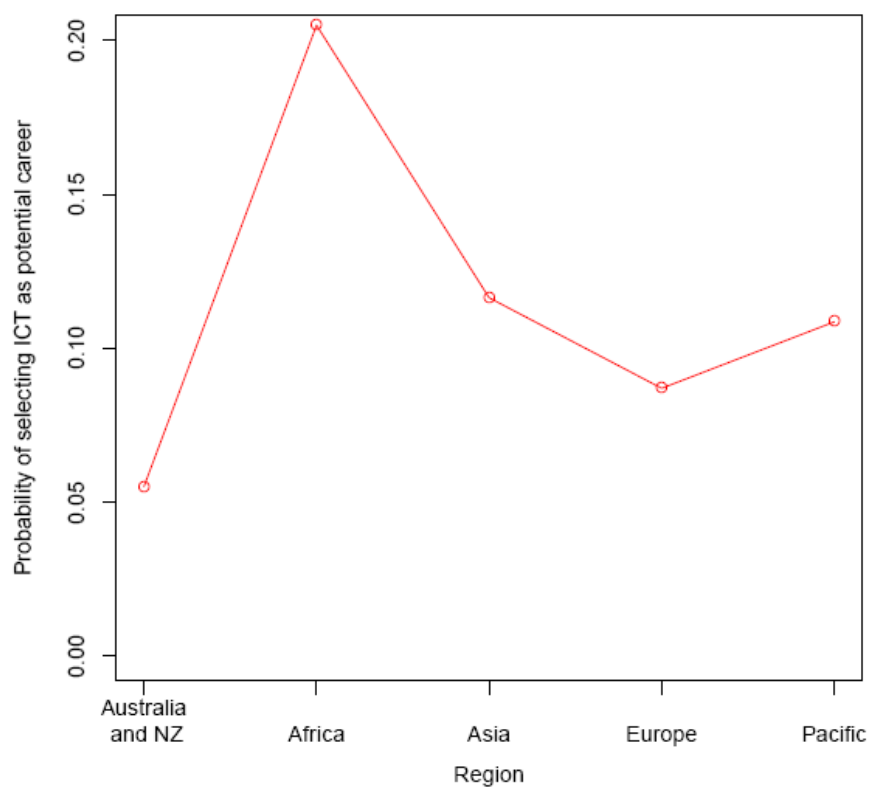

Figure 5: Fitted relationship between ethnic background and interest in ICT career

Figure 6 shows that mother's education had a positive influence on students' interest in ICT career, that is, students whose mothers had a higher level of education were more likely to be interested in this kind of career. However, this effect was largest for students whose mothers had 11 or 12 years of education; the effect decreased for students whose mothers had post-secondary education. 


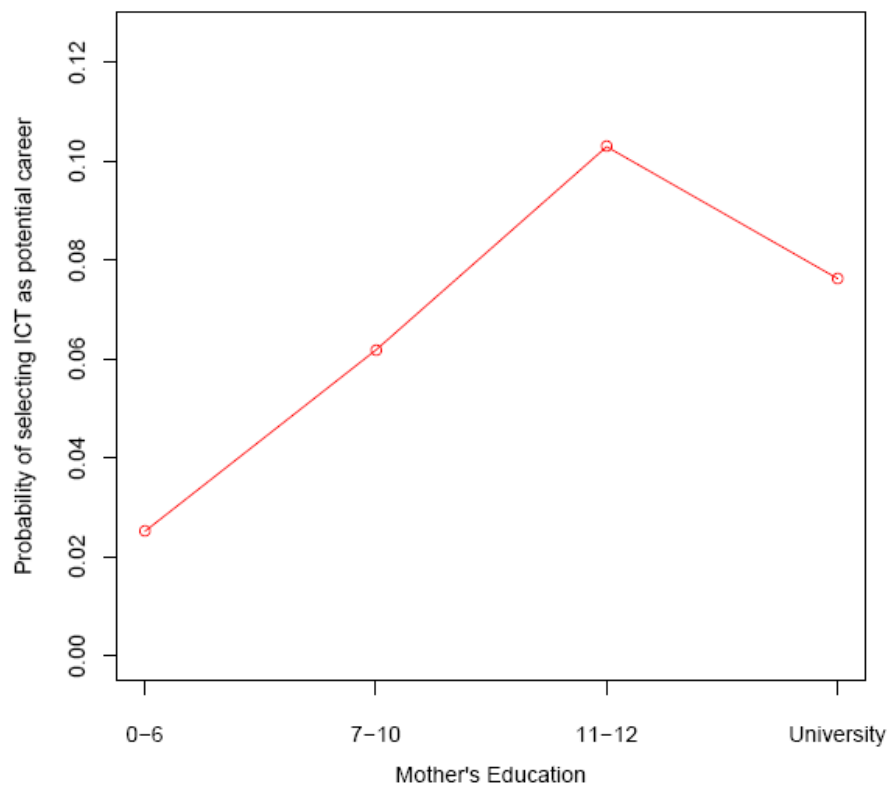

Figure 6: Fitted relationship between mother's level of education and daughter's interest in ICT career

It appears that fathers' use of computers also had a positive effect on the students' interest in an ICT career (Figure 7). Surprisingly, girls whose mothers used computers were less likely to consider ICT as a career option (Figure 8). 


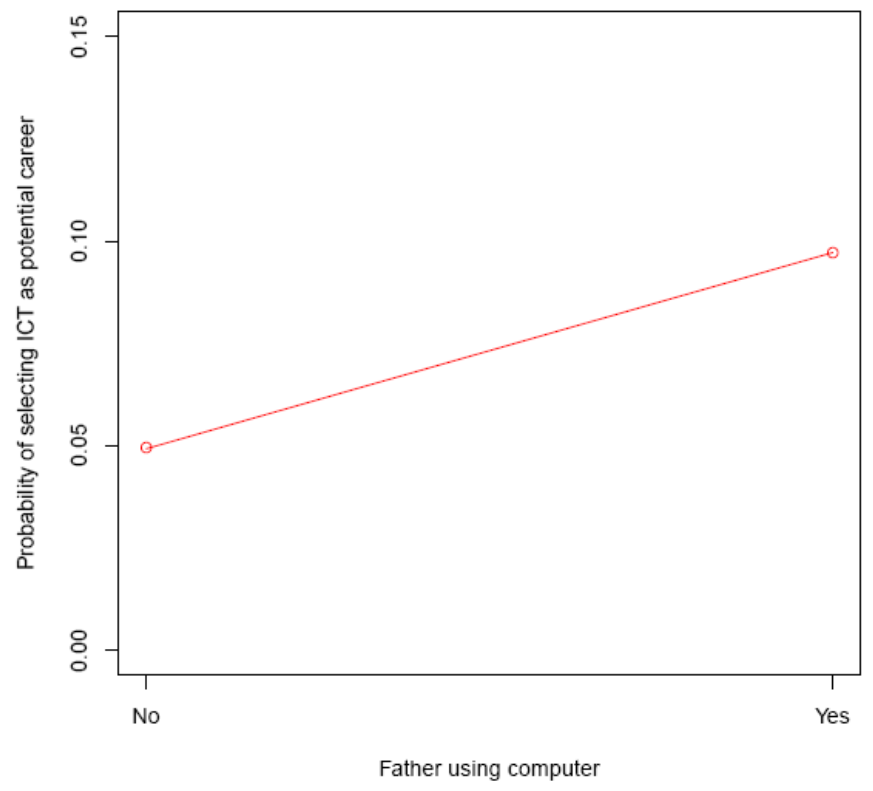

Figure 7: Fitted relationship between father's use of computer and daughter's interest in ICT career

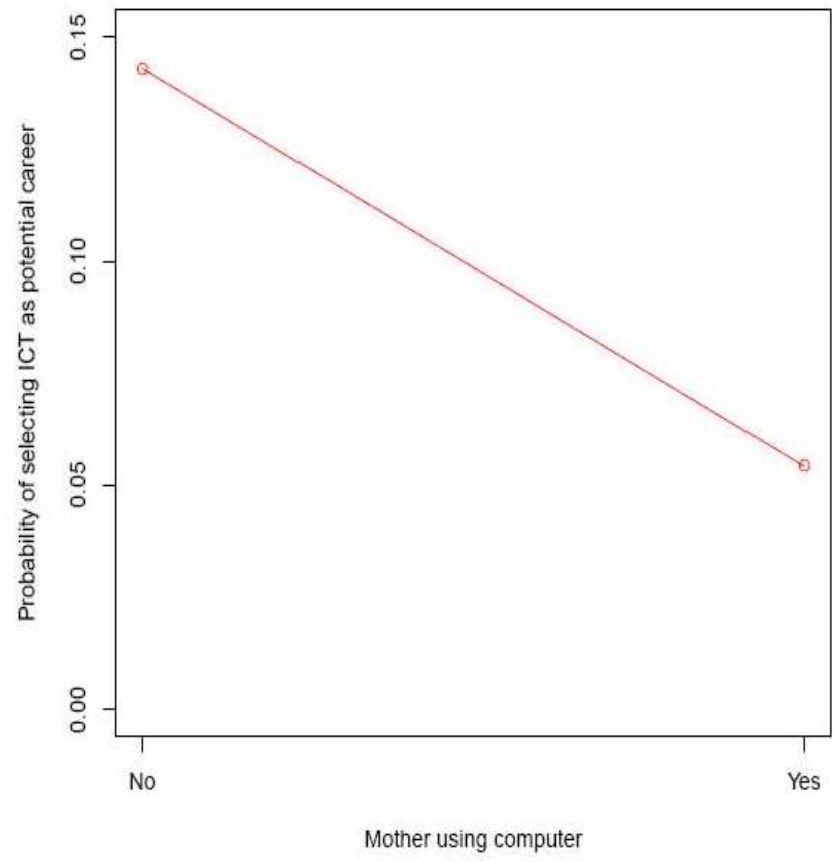

Figure 8: Fitted relationship between mother's use of computers and daughter's interest in ICT career 


\section{Discussion}

The findings of this study indicate a positive attitude towards computers and ICT among the participating girls; they reported a relatively high level of interest in ICT and rather high levels of self-efficacy in computing skills. These findings seem somewhat "optimistic" in comparison to those reported in the literature (Hargittai \& Shafer, 2006; Volman \& van Eck, 2001; von Hellens $\&$ Nielsen, 2005). Disappointingly, the relatively high levels of interest and self-efficacy did not translate into willingness to embrace ICT as an option for further study or career. ICT merely occupied the eighth place in the ranking of popular career choices and was outnumbered by a career in Creative Arts or Health and a career in Society and Culture or Education. Only a career in engineering or agriculture was considered a less attractive option that ICT. Similar findings were reported in a large European study by Grass-Valazquez et al. (2009), which showed a similar lack of correlation between girls' enjoyment of and confidence in using ICT and their willingness to pursue ICT studies or careers.

Another finding revealed that girls in earlier year levels were more likely to consider an ICT career than their older peers and that exposure to a greater variety of different software tools and services increased students' interest in an ICT career. Final-year students reported a much lower level of exposure to the more advanced computing skills such as database skills, programming, and Web data retrieval than their peers from the earlier year level; a finding supported by the literature (Craig et al., 2007).

Girls of an immigrant background, particularly those of African and Asian roots, expressed a greater interest in an ICT career than those whose both parents were born in Australia or New Zealand. Girls of African background represent a particularly interesting cohort in that their interest in ICT studies and careers was not inhibited by, what could be regarded as, multiple "educational disadvantages." Firstly, these girls had only recently immigrated to Australia from mostly developing countries and had to learn English and adapt to a different society and culture; this could not have been an easy task considering that majority of them did not speak English at home. Secondly, twice as many girls of African background, compared to the others, had both parents unemployed and had both parents with the lowest level of education. Thirdly, a large percentage of girls of African background did not have a computer at home, and they started using computers much later than the rest of the respondents. The positive attitudes and greater interest in ICT might be explained by the fact that the majority of girls of African background attended a single-sex school; this is consistent with the evidence reported in the literature (Bosire et al., 2008; Scott, 1996).

\section{Conclusion}

The research study reported in this article investigated the perceptions of ICT skills, studies, and careers among female secondary school students in an educationally disadvantaged metropolitan region of Melbourne, as well as females from regional secondary schools outside of Melbourne. The analysis of the study findings revealed that, overall, female students had positive perceptions of ICT; however, this interest did not translate into consideration of ICT as a career choice. This suggests that there is a large group of female students who might be attracted to ICT studies and careers if provided with adequate encouragement and more information about the opportunities that ICT presents. The results of statistical modelling indicated that, apart from factors such as interest in computers and family background, exposure to different software tools and services, particularly in earlier years of secondary school, played an important role in shaping female students' interest in an ICT career. This indicates that an intense and sustained contact with ICT, beginning in early years of secondary school, may serve as a catalyst for considering ICT as a 
future career. An investigation to identify and recommend strategies that would best respond to the issues revealed in this study is currently in progress.

This research expanded on an earlier study (Miliszewska \& Sztendur, 2009) and facilitated a stronger verification of the relationships between academic and environmental factors and girls' interest in ICT career. Its findings may help educators, employers, and businesses effectively understand and address female students' attitudes towards ICT and their interest in ICT careers; and, serve as a source of information for educators, employers, and businesses in planning, design, and implementation of targeted strategies aimed at encouraging girls from economically and socially disadvantaged backgrounds to consider a career in ICT.

\section{References}

Adya, M., \& Kaiser, K. M. (2005). Early determinants of women in the IT workforce: A model of girls' career choices. Information Technology and People, 18(3), 230-259.

Babin, R., Grant, K., \& Sawal, L. (2008). Identifying influencers in high school student ICT career choice. Proceedings of the Information Systems Educators' Conference (ISECON 2008), Phoenix, Arizona, 117.

Blackmore, J., Hardcastle, L., Bamblett, E., \& Owens, J. (2003). Effective use of information and communication technology (ICT) to enhance learning for disadvantaged schools students. Deakin Centre for Education and Change, Institute of Koorie Education Deakin University, Institute of Disability Studies Deakin University. Retrieved 9 November, 2008 from http://www.dest.gov.au/archive/schools/publications/2003/ICT/ICTreport.pdf

Bosire, J., Mondon, H., \& Barmao, A. (2008). Effect of streaming by gender on student achievement in mathematics in secondary schools in Kenya. South African Journal of Education, 28, 595-607.

Courtney, L., Timms, C., \& Anderson, N. (2006). I would rather spend time with a person than a machine: Qualitative findings from the girls and ICT survey. In A. Ruth (Ed.), Quality and impact of qualitative research, 3rd annual QualIT Conference, Brisbane, Australia, Griffith University, 51-57.

Craig, A., Fisher, J., \& Lang, C. (2007). ICT and girls: The need for a large scale intervention programme. Proceedings of the 18th Australasian Conference on Information Systems, Toowoomba, 761-769.

DCITA. (2006). Building Australian ICT skills. [Report.] Canberra: Commonwealth of Australia.

Derbyshire, H. (2003). Gender issues in the use of computers in education in Africa. Retrieved 17 February, 2010 from http://schoolnetafrica.org/fileadmin/resources/Gender_Report.pdf

Eidelman, L., \& Hazzan, O. (2006). The shrinking pipeline in Israeli high schools. In E. M. Trauth (Ed.), Encyclopedia of gender and information technology (pp. 1092-1098). Hershey, PA: Idea Group Reference.

Fox, J. (2003). Effect displays in R for generalised linear models. Journal of Statistical Software, 8(15), 127. Retrieved 17 February, 2010 from http://www.jstatsoft.org/v08/i15

Gates, J. (2002). Women's career influences in traditional and non-traditional fields. Poster presented at the Biennial Meeting of the Society for Research in Adolescence, New Orleans, LA. Retrieved 15 January, 2009 from http://www.eric.ed.gov/ERICDocs/data/ericdocs2sql/content storage 01/0000019b/80/1a/72/5b.pdf

Goode, J., Estrella, R., \& Margolis, J. (2006). Lost in translation: Gender and high school computer science. In J. M. Cohoon \& W. Aspray (Eds.), Women and information technology: Research on underrepresentation. Cambridge, Massachusetts: The MIT Press.

Grass-Valazquez, A., Joyce, A., \& Debry, M. (2009). White paper: Women and ICT - Why are girls still not attracted to ICT studies and careers? Retrieved 17 February, 2010 from http://blog.eun.org/insightblog/upload/Women and ICT FINAL.pdf 
Hargittai, E., \& Shafer, S. (2006). Differences in actual and perceived online skills: The role of gender. Social Science Quarterly, 87(2), 432-448.

IFACProject. (2008). Preparing young girls for science and technology careers: Information booklet for career counselors. Retrieved 15 January, 2009 from http://ifac-project.eu/downloads/preparing-younggirls-for-science-and-technology-careers-information-booklet-for-career-counsellors-athens-june$\underline{2008 / \text { view }}$

Klein, S. S. (2007). Handbook for achieving gender equity through education (2nd ed.). Routledge.

Margolis, J., \& Fisher, A. (2002). Unlocking the clubhouse: Women in computing. Massachusetts: MIT Press.

Miliszewska, I. (2006). Gender bias in computer courses in Australia. In E. M. Trauth (Ed.), Encyclopedia of gender and information technology (pp. 501-506). Hershey, PA: Idea Group Reference.

Miliszewska, I., \& Sztendur, E. M. (2009). Girls from low socio-economic backgrounds: Factors influencing their interest in ICT study and career. Proceedings of the Americas Conference on Information Systems (AMCIS), San Francisco, USA. Electronic proceedings, paper 412. Retrieved from http://aisel.aisnet.org/amcis2009/412

Moore, C. (1994). Attitudes towards computers: The influence of sex stereotypes, experience, ownership and mathematics. Unisa Psychologia, 21(1), 20-27.

PartICipaTion Summit. (2005). DCITA. Retrieved 15 January, 2009 from http://archive.dcita.gov.au/2005/09/participation_summit

Ratsatsi, D. M. (2002). Botswana: Equity and access in ICTs: Are we reaching the audience we intended to address? TechKnowLogia, Knowledge Enterprise, Inc. Retrieved 17 February, 2010 from http://schoolnetafrica.org/fileadmin/resources/Equity_and_Access_in_ICTs_Botswana.pdf

R Development Core Team (2008). R: A Language and Environment for Statistical Computing. R Foundation for Statistical Computing, Vienna, Austria. Retrieved 15 January, 2009 from http://www.R-project.org

Scott, V. A. (1996). Why are girls underrepresented? Ten years on. Australian Educational Computing, 11(1), 17-21.

Smith, L. B. (2000). The socialization of females with regard to a technology-related career: Recommendations for change. Meridian: A Middle School Computer Technologies Journal, 3(2). Retrieved 15 January, 2008 from http://www.eric.ed.gov/ERICDocs/data/ericdocs2sq1/content_storage_01/0000019b/80/16/d9/c2.pdf,

Symonds, J. (2007). Choice and possible selves in the Midlands: A comparison of Year 11 pupils' education and employment aspirations to their wider world of hopes and fears, pre-GCSE examination. Paper presented at the British Educational Research Association New Researchers/Student Conference, 5 September, University of London. Retrieved 2 February, 2009 http://www.leeds.ac.uk/educol/documents/165911.doc

Teese, R. (2006). Condemned to innovate. Griffith Review, February. Retrieved 10 December, 2008 from http://www.griffith.edu.au/griffithreview

Trauth, E. M. (2002). Odd girl out: An individual differences perspective on women in the IT profession. Information Technology and People, 15(2), 98-118.

Trauth, E. M. (2006). An agenda for research on gender diversity in the global information economy. In E. M. Trauth (Ed.), Encyclopedia of gender and information technology (pp. xxix-xxxiii). Hershey, PA: Idea Group Reference.

Venables, W. N., \& Ripley, B. D. (2002). Modern applied statistics with S-Plus (4th ed.) New York: Springer Verlag.

Volman, M., \& van Eck, E. (2001). Gender equity and information technology in education: The second decade. Review of Educational Research, 71(4), 613-663. 
Volman, M., van Eck, E., Heemskerk, I., \& Kuiper, E. (2005). New technologies, new differences. Gender and ethnic differences in pupils' use of ICT in primary and secondary education. Computers \& Education, 45(1), 35-55.

von Hellens, L. A., \& Nielsen, S. H. (2005). Australian women in IT. Communications of the ACM, 44(7), 46-52.

von Hellens, L. A., Nielsen, S. H., \& Trauth, E. M. (2001). Breaking and entering the male domain. Women in the IT industry. Proceedings of the 2001 ACM SIGCPR Conference on Computer Personnel Research, San Diego, USA, 116-120.

\section{Biographies}

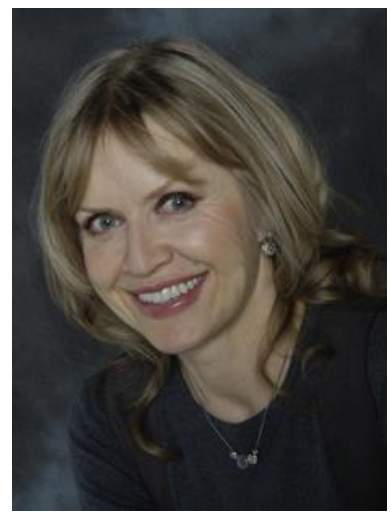

Dr Iwona Miliszewska is Associate Professor in computer science at Victoria University in Melbourne, Australia. She has led and participated in research projects involving transnational education, effective teaching methods, and females in ICT, and has published in these areas. In 2008/2009 Iwona led a research project investigating the perceptions of ICT studies and careers among female secondary school students from low socioeconomic backgrounds.

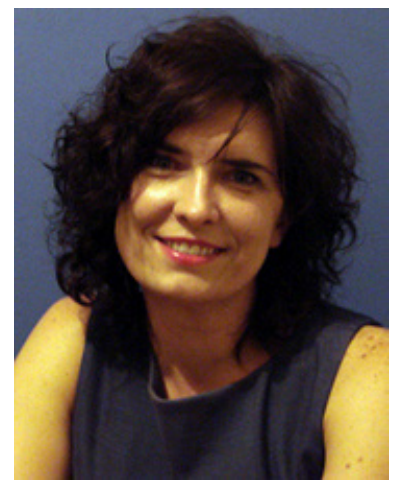

Dr Ewa Sztendur is a Research Fellow in the Centre for Innovation in Learning and Teaching at Victoria University in Melbourne, Australia. She is a statistician with special expertise in experimental design. Ewa has been involved in numerous research projects related to the issues of higher education, including widening participation, gender equity, student use of technology, and student retention and performance. 